\title{
Distribution of planktonic microcrustaceans (Cladocera and Copepoda) in lentic and lotic environments from the semiarid region in northeastern Brazil
}

\author{
Leidiane P. Diniz1,3 (D), Cláudio S. de Morais Júnior², (D), Ittalo L.S. Medeiros ${ }^{3}$ (D), \\ Alef J. da Silva ${ }^{2,3}$ (1) , Alan P. Araújo ${ }^{4,3}$ (D), Tâmara A. Silva ${ }^{5}$ (1) \& Mauro de Melo Júnior ${ }^{3}$ (i)
}

\footnotetext{
1. Universidade Estadual de Maringá (UEM), Laboratório Zooplâncton, Núcleo de Pesquisa em Limnologia, Ictiologia e Aquicultura (Nupélia), Av. Colombo, 5.790, 87020-900 Maringá, PR, Brazil. (leidianeediniz@gmail.com)

2. Universidade Federal de São Carlos (UFSCar), Departamento de Hidrobiologia, Via Washington Luis, Km 235, 13565-905, São Carlos, SP, Brazil. (claudiosmjunior@gmail.com; a.lef93@hotmail.com)

3.Universidade Federal Rural de Pernambuco (UFRPE), Laboratório de Ecologia do Plâncton (LEPLANC), Departamento de Biologia, Rua Dom Manoel de Medeiros, s/n, 52171-900, Recife, PE, Brazil. (ittalom@gmail.com, mmelojunior@gmail.com)

4. Universidade Federal de Goiás (UFG), Instituto de Ciências Biológicas, Departamento de Ecologia, Av. Esperança, s/n Campus Samambaia, 74690-900, Goiânia, GO, Brazil. (alannpedro@gmail.com)

5.Universidade do Estado da Bahia (UNEB), Departamento de Educação, Campus VIII, Rua do Gangorra, 503, CHESH, 48600-000, Paulo Afonso, BA, Brazil. (tamaraalmeidas@yahoo.com.br)
}

ABSTRACT. The present study aimed to inventory the biodiversity of planktonic microcrustaceans (Cladocera and Copepoda) in 44 environments from the semiarid region of Brazil, increasing the knowledge about zooplankton community, including phytophilous species. Between 2011 and 2017 , organisms were collected in a non - systematic way in the states of Rio Grande do Norte, Pernambuco, Ceará and Paraíba. A total of 60 species of planktonic microcrustaceans were identified, of which 52 were cladocerans and eight were copepods. The basin that presented the highest richness was Pajeú River with 41 species. Nevertheless, the extrapolated number of species shows an increasing tendency for this basin. The genus composition was different between the basins, with Moxotó basin (Pernambuco) being isolated from the others, probably since lagoons were the only type of environment sampled in this basin. Richness and abundance patterns were higher for the basins where sampling was mainly performed in lentic environments, such as Pajeú and Moxotó. Microcrustacean inventories and long-term studies need to be conducted more frequently to better understand the biodiversity of continental aquatic ecosystems in the semiarid region of Brazil.

KEYWORDS. Zooplankton, Neotropical, shallow lakes, Caatinga.

RESUMO. Distribuição de microcrustáceos planctônicos (Cladocera e Copepoda) em ambientes lênticos e lóticos do semiárido brasileiro. O presente estudo objetivou inventariar a biodiversidade de microcrustáceos planctônicos (Cladocera e Copepoda) em 44 mananciais da região semiárida do Brazil, ampliando o conhecimento da comunidade zooplanctônica desta região, incluindo as espécies fitófilas. Os organismos foram coletados de modo não sistemático entre 2011 e 2017, nos estados do Rio Grande do Norte, Pernambuco, Ceará e Paraíba. Um total de 60 espécies de microcrustáceos planctônicos foram identificadas, sendo 52 de cladóceros e oito de copépodes. A bacia que apresentou maior riqueza foi a do rio Pajeú com 41 espécies. Mesmo assim, o número extrapolado de espécies mostra tendência de aumento para essa bacia. A composição dos gêneros foi diferente entre as bacias hidrográficas, sendo a bacia do Moxotó (Pernambuco) isolada das demais, talvez porque nesta bacia as lagoas foram o único tipo de ambiente amostrado. Os padrões de riqueza e de abundância se mostraram mais elevados para as bacias ondem a amostragem foi realizada principalmente em ambientes lênticos, como a do Pajeú e do Moxotó. Inventários de microcrustáceos e estudos de longa duração precisam ser maximizados para ampliação do conhecimento da biodiversidade dos ecossistemas aquáticos continentais da região semiárida brasileira.

PALAVRAS-CHAVE. Zooplâncton, Neotropical, lagos rasos, Caatinga.

Ecosystems in the semiarid region of Brazil encompass artificial reservoirs and natural shallow lakes, as well as streams and rivers. These systems present peculiarities in semiarid landscapes, characterized by complex climatic patterns and irregular rainfall indices (Medeiros \& MaltchiK, 2001; Maltchik \& Medeiros, 2006). Organisms that inhabit these habitats are prone to strong changes in their composition and dynamics (CARDOSO et al., 2012). Nevertheless, these environments hold high species biodiversity, since the stresses caused by irregular seasonality tend to favor higher microcrustacean diversity (GüNTZEL et al., 2010).

Planktonic microcrustaceans, including phytophilous species, that inhabit plankton in the shallow littoral zone play a special role in energy transfer (Melão et al., 2005) as they provide nutrients for deeper/bottom layers of continental aquatic ecosystems through their fecal pellets (SHATOva et al., 2012) and carcasses. Although there are several surveys about microcrustaceans from continental waters around the world, much remains to be understood regarding their biodiversity 
patterns. The last global survey of cladocerans comprised 620 species recorded in freshwater ecosystems around the world, with 186 species found in the Neotropical region (ForRó et al., 2008). For freshwater copepods, 2,814 species have been recorded worldwide, with the Neotropical region presenting the second highest richness with 561 species (Boxshall \& Defaye, 2008).

Zooplankton studies in the Brazilian northeastern region began with the works of WRIGHT (1935), BREHM \& ThOMSEn (1936), Brehm $(1937,1938)$, and AHLSTROM (1938). A few decades after these pioneering studies, new studies $\mathrm{s}$ were carried out in Paraíba (NoRdi \& WATANABE, 1978) and Maranhão (ReID \& TURNER, 1988). In Pernambuco the first studies of zooplankton were implemented by SCHUBART (1938, 1942), followed by Neumann-Leitão \& Souza (1987) and NEUMANN-LeITÃo et al., (1989). After that, other researchers collected and reviewed works from the region (REID, 1989). Although the number of studies about planktonic microcrustaceans from continental waters in the semiarid region have increased in recent years (ALMEIDA et al., 2009; SOARES \& ElMOOR-LOUREIRO, 2011; DinIZ et al., 2013; Melo et al., 2014; Sousa et al., 2015a,b; MedeIros \& MELO-JÚNIOR, 2016; DinIz \& MELO-JÚNIOR, 2017; CABRAL et al., 2019), many are still difficult to find and access, being found in particular libraries and collections (MELO-JÚNIOR et al., 2007; Paranhos et al., 2013). According to Silva \& Perbiche-Neves (2017), 45\% of studies about microcrustaceans in Brazil encompasses only three of the most populous Brazilian states (São Paulo, Minas Gerais and Paraná).

Indeed, the knowledge concentrates around a few research centers, with focus on particular localities, limiting the taxonomic and biogeographic knowledge of the species (Debastiani-JúNIOR et al., 2015). The small amount of research about the semiarid biodiversity has led to the misperception of poor aquatic biota with little endemism (MALtchiK \& Medeiros, 2006). Further research is needed focusing on the taxonomy and ecology of microcrustaceans of more regions in order to reduce biodiversity loss and improve conservation measures in continental aquatic habitats. In addition, as microcrustaceans can be used in environmental biomonitoring and ecotoxicological studies (SILVA, 2011; MoREIRA et al., 2014), increasing the number of biodiversity studies could further improve this field of knowledge.

Therefore, the goal of the present study was to inventory the planktonic microcrustaceans (Cladocera and Copepoda) in 44 lentic and lotic habitats in the Brazilian semiarid. We also aimed to increase knowledge about zooplankton, including phytophilous species. This is one of the largest studies about freshwater zooplankton fauna in the northeastern region, encompassing different states and hydrographic basins with the highest number of sampled waterbodies.

\section{MATERIAL AND METHODS}

Study area. Our study was carried out in 44 environments from the semiarid region in northeastern Brazil (lentic, lotic, natural and artificial), distributed among the states of Rio Grande do Norte, Pernambuco, Ceará and Paraíba. The environments belong to eight different sub-basins, distributed into two hydrographic regions: the Eastern Northeastern Atlantic region and the São Francisco region (Appendix, Fig. 1) (MMA, 2006a).

The Eastern Northeastern Atlantic region includes the states of Ceará (CE), Rio Grande do Norte (RN), Paraíba (PB) and the coastal part of the states of Pernambuco (PE) and Alagoas (AL). We sampled 10 environments in the Piranhas-Apodi sub-basin (RN-PB), with an area of 59,701.22 $\mathrm{km}^{2}$, and one environment in the Jaguaribe basin - Salgado subdivision (CE), which occupies an area of $12,882.48 \mathrm{~km}^{2}$.

The São Francisco region includes the states of Minas Gerais (MG), Bahia (BA), Pernambuco (PE) and some

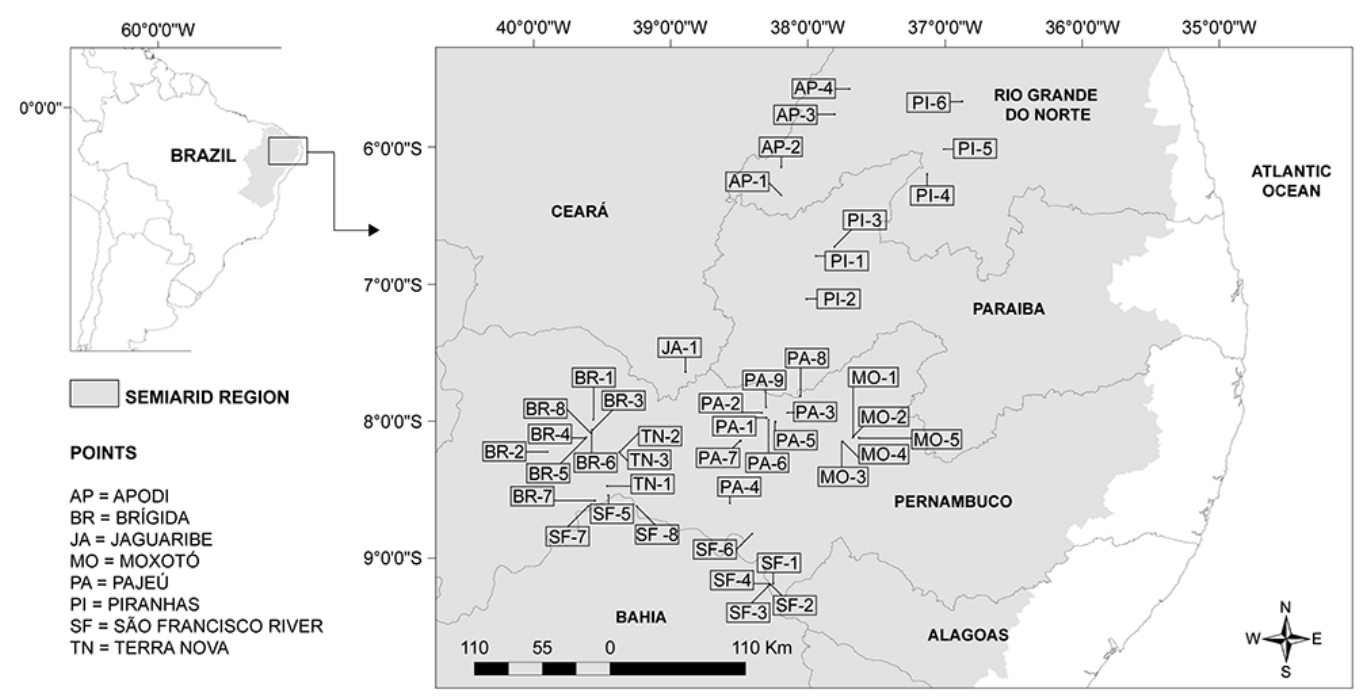

Fig. 1. Location of the 44 environments studied in the semiarid region of northeastern Brazil. A1 to A4, Apodi basin; B1 to B8, Brígida basin; J1, Jaguaribe basin; M1 to M5, Moxotó basin; P1 to P9, Pajeú basin; R1 to R6, Piranha basin; S1 to S8, São Francisco basin; T1 to T3, Terra Nova basin. 
regions near the river in the states of Alagoas and Sergipe (SE). Most of the studied environments were distributed in the fraction of the São Francisco sub-basin, located in Pernambuco state, comprising a total area of 114,375.61 $\mathrm{km}^{2}$. Eight environments were sampled in the Brígida River sub-basin; five in the Moxotó sub-basin; nine in the Pajeú sub-basin, and 11 points in stretches of the São Francisco River. Three reservoirs were sampled in the Terra Nova sub-basin (MMA, 2006b).

Procedures for sampling and analyzing biological material. Zooplankton samples were carried out in a nonsystematic manner between January 2011 and May 2016, with some samples collected in littoral zone and others in pelagic zone of the environments. Samples were obtained using a plankton net with $45 \mu \mathrm{m}$ size mesh and graduated container. The amount of filtered water varied in each environment (Appendix). The organisms were fixed with 4\% neutral formalin. Samples were registered and deposited in the Zooplankton Collection at the UFRPE (CZ-UFRPE).

In the laboratory, cladocerans and copepods were studied under optical microscope and stereomicroscope and were identified using usual dissection methods for microcrustaceans and specialized bibliography (e.g. REID, 1985; Matsumura-Tundisi, 1986; SMirnov, 1996; ElmoORLoureiro, 1997; PerbiCHe-Neves et al., 2015). For each sample, three $2 \mathrm{~mL}$ replicates were placed in a SedgwickRafter-type chamber, prepared specifically for this volume. For each replicate, a minimum of 100 individuals should be counted, totaling at least 300 individuals per sample, which maintains high chances of detecting rare species. Samples with a low number of specimens $(<100$ individuals per subsample) were completely analyzed.

Data analysis. Data was initially treated as frequency of occurrence (\%), abundance of individuals (ind. $\mathrm{m}^{-3}$ ), and species richness. After this, we plotted a rarefaction curve based on the number of individuals, which was extrapolated to estimate and compare species richness among different river basins. Each basin was represented by one curve, with confidence intervals (95\%) generated by the bootstrap method with 100 replications (CHAO \& Jost, 2012). For this analysis, we used the iNEXT package in R (HsIEH et al., 2016; R Core Team, 2016).

To verify possible similarities between basins, a Cluster Analysis was used through the Bray-Curtis dissimilarity index obtained using the Proxy package for R (MEYER \& BuchtA, 2018). In addition, to verify differences in genus composition between basins, the Permutational multivariate analysis of variance (PERMANOVA, "Adonis" function, see ANDERSON et al., 2001) was used, with distance matrix calculated using the Bray-Curtis method and visualized with Non-Metric Multidimensional Scaling (NMDS), performed in the Vegan package (OKSANEN et al., 2018). All analyses were performed in software R (R CORE TEAM, 2016).

\section{RESULTS}

We identified 60 species of planktonic microcrustaceans: 52 Cladocera and eight Copepoda. Cladocerans were distributed among the families Sididae (6 species) Bosminidae (3), Moinidae (2), Daphniidae (6) Macrothricidae (5), Ilyocryptidae (1) and Chydoridae (30). Copepods were distributed among Diaptomidae (3) and Cyclopidae (5) (Tab. I).

The most frequently found species were: Ceriodaphnia cornuta Sars, 1885 (43.18\%), Diaphanosoma spinulosum Herbst, 1975 (36.36\%), Macrothrix elegans Sars, 1901 (34.09\%), and Notodiaptomus cearensis (Wright, 1936) (31.82\%). The naupliar forms reached $95.45 \%$. The other species had frequencies less than $30 \%$ (Tab. I).

The Pajeú River basin had the highest richness with 41 species, followed by the Brígida River (31), while the lowest richness was found in the Apodi River basin (1) (Tab. I). Most river basins reached the asymptote for the number of species, through collected individuals. However, the greatest richness was found in the Pajeú River basin, where the extrapolated number shows an increasing trend (Fig. 2).

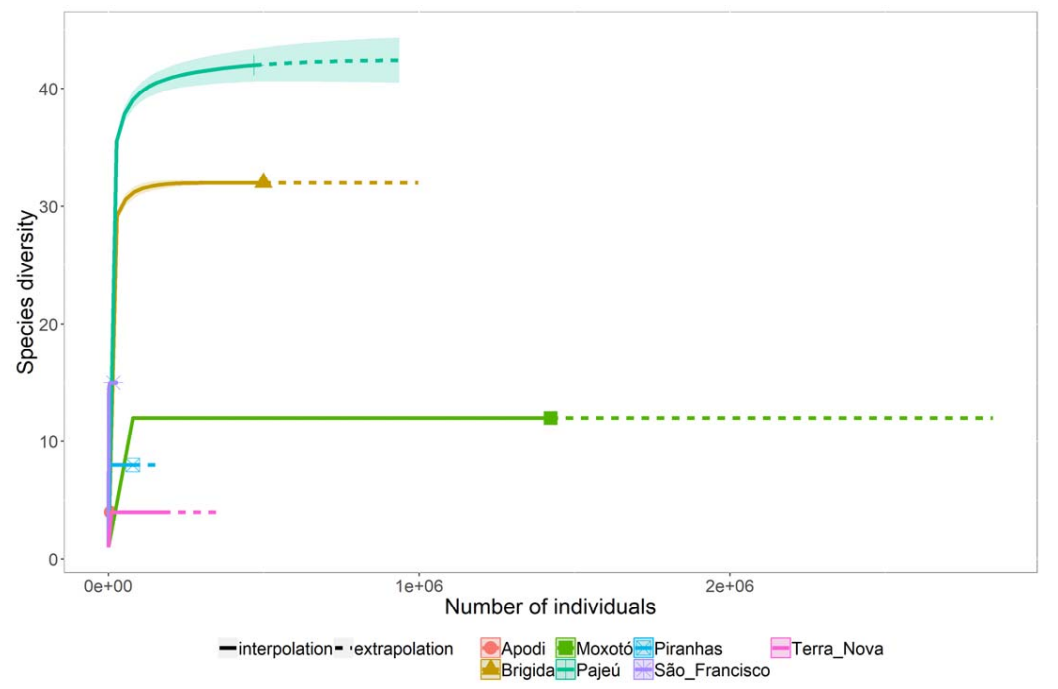

Fig. 2. Rarefaction and extrapolation curves based on the number of microcrustaceans collected from seven basins in the semiarid region of northeastern Brazil. The shaded area represents the $95 \%$ confidence interval. 
Tab. I. List of microcrustaceans (Cladocera and Copepoda) species collected in the semiarid ecosystems, Brazil (F.O., frequency of occurrence; ANT, Antarctic; AU, Australasian; AT, Afrotropical; NA, Nearctic; NT, Neotropical; OL, Oriental; PA, Palearctic; PAC, Pacific ocean).

\begin{tabular}{|c|c|c|c|c|c|c|c|c|c|}
\hline \multirow[b]{2}{*}{ Species } & \multicolumn{7}{|c|}{ Basins } & \multirow[b]{2}{*}{ F.O. } & \multirow[b]{2}{*}{ Global distribution } \\
\hline & Apodi & Brígida Jaguaribe & Moxotó & Pajeú & Piranhas & $\begin{array}{c}\text { São } \\
\text { Francisco }\end{array}$ & $\begin{array}{l}\text { Terra } \\
\text { Nova }\end{array}$ & & \\
\hline \multicolumn{10}{|l|}{$\begin{array}{l}\text { CLADOCERA } \\
\text { SIDIDAE }\end{array}$} \\
\hline Diaphanosoma fluviatile Hansen, 1899 & & & & $\mathrm{X}$ & & & & 2.27 & NT \\
\hline $\begin{array}{l}\text { Diaphanosoma polyspinum } \\
\text { Korovchinsky, } 1982\end{array}$ & & & & $\mathrm{X}$ & & & & 2.27 & NT \\
\hline $\begin{array}{l}\text { Diaphanosoma spinulosum Herbst, } \\
1975\end{array}$ & $\mathrm{X}$ & $\mathrm{X}$ & $\mathrm{X}$ & $\mathrm{X}$ & $\mathrm{X}$ & & & 36.36 & NT \\
\hline Latonopsis australis Sars, 1888 & & & & $\mathrm{X}$ & & & & 4.55 & $\begin{array}{c}\text { AT; AU; NA; NT; OL; } \\
\text { PAC; PA }\end{array}$ \\
\hline Pseudosida bidentata Herrick, 1884 & & $\mathrm{X}$ & & $\mathrm{X}$ & & & & 4.55 & NT \\
\hline Sarsilatona serricaudata (Sars, 1901) & & $\mathrm{X}$ & & & & & & 2.27 & NA; NT \\
\hline \multicolumn{10}{|l|}{ BOSMINIDAE } \\
\hline Bosminopsis deitersi Richard, 1895 & & & & & & $\mathrm{X}$ & & 2.27 & $\begin{array}{c}\text { AU; AT; NA; NT; } \\
\text { OL; PA }\end{array}$ \\
\hline Bosmina freyi De Melo \& Hebert, 1994 & & & & $\mathrm{X}$ & & $\mathrm{X}$ & $\mathrm{X}$ & 13.64 & $\begin{array}{c}\text { AT; ANT; AU; NA; NT } \\
\text { OL; PAC; PA }\end{array}$ \\
\hline Bosmina hagmanni Stingelin, 1904 & & & & & & & $\mathrm{X}$ & 2.27 & NA; NT \\
\hline \multicolumn{10}{|l|}{ MOINIDAE } \\
\hline Moina micrura Kurz, 1875 & & $\mathrm{X}$ & $\mathrm{X}$ & $\mathrm{X}$ & & & $\mathrm{X}$ & 29.55 & $\begin{array}{c}\text { AT; AU; NA; NT; OL; } \\
\text { PAC; PA }\end{array}$ \\
\hline Moina reticulata (Daday, 1905) & & $\mathrm{X}$ & & & & & & 4.55 & AT; NT \\
\hline \multicolumn{10}{|l|}{ DAPHNIIDAE } \\
\hline Ceriodaphnia cornuta Sars, 1885 & & $\mathrm{X}$ & $\mathrm{X}$ & $\mathrm{X}$ & & $\mathrm{X}$ & $\mathrm{X}$ & 43.18 & $\begin{array}{c}\text { AT; AU; NA; NT; OL; } \\
\text { PAC; PA }\end{array}$ \\
\hline Daphnia gessneri Herbst, 1967 & & & & $\mathrm{X}$ & & $\mathrm{X}$ & & 13.64 & NT \\
\hline Simocephalus acutirostris (King, 1853) & & & & $\mathrm{X}$ & & & & 4.55 & AU; OL; PAC \\
\hline $\begin{array}{l}\text { Simocephalus latirostris Stingelin, } \\
1906\end{array}$ & & & & $\mathrm{X}$ & & & & 2.27 & NT \\
\hline Simocephalus serrulatus (Koch, 1841) & & & & $\mathrm{X}$ & & & & 2.27 & $\begin{array}{c}\text { AT; AU; NA; NT; OL; } \\
\text { PAC; PA }\end{array}$ \\
\hline Simocephalus sp. & & & & & $\mathrm{X}$ & & & 2.27 & \\
\hline \multicolumn{10}{|l|}{ MACROTHRICIDAE } \\
\hline Grimaldina brazzai Richard, 1892 & & $\mathrm{X}$ & & $\mathrm{X}$ & & & & 6.82 & AT; AU; NT; OL \\
\hline Macrothrix elegans Sars, 1901 & & $\mathrm{X}$ & $\mathrm{X}$ & $\mathrm{X}$ & & & & 34.09 & NT \\
\hline $\begin{array}{l}\text { Macrothrix superaculeata (Smirnov, } \\
1982 \text { ) }\end{array}$ & & & & $\mathrm{X}$ & & & & 2.27 & NT \\
\hline Macrothrix sp. & & & & & & $\mathrm{X}$ & & 2.27 & \\
\hline \multicolumn{10}{|l|}{ ILYOCRYPTIDAE } \\
\hline Ilyocryptus spinifer Herrick, 1882 & & $\mathrm{X}$ & $\mathrm{X}$ & $\mathrm{X}$ & & & & 13.64 & $\begin{array}{c}\text { AT; AU; NA; NT; OL; } \\
\text { PAC; PA }\end{array}$ \\
\hline \multicolumn{10}{|l|}{$\begin{array}{l}\text { CHYDORIDAE } \\
\text { CHYDORINAE }\end{array}$} \\
\hline Alonella dadayi Birge, 1910 & & $\mathrm{X}$ & & & & & & 2.27 & NT \\
\hline Alonella sp. & & & & & & $\mathrm{X}$ & & 2.27 & \\
\hline Chydorus eurynotus Sars, 1901 & & & & $\mathrm{X}$ & & & & 2.27 & AT; AU; NT; OL; PAC \\
\hline Chydorus nitidulus (Sars, 1901) & & $\mathrm{X}$ & & & & & & 2.27 & NT \\
\hline Chydorus pubescens Sars, 1901 & & & $\mathrm{X}$ & $\mathrm{X}$ & & & & 9.09 & AT; AU; NT; OL \\
\hline Chydorus sp. & & & & & $\mathrm{X}$ & $\mathrm{X}$ & & 6.82 & \\
\hline Dadaya macrops (Daday, 1898) & & $\mathrm{X}$ & & & & & & 2.27 & AT; AU; NT; OL; PAC \\
\hline Dunhevedia odontoplax Sars, 1901 & & $\mathrm{X}$ & & & & & & 4.55 & NT \\
\hline
\end{tabular}


Tab. I. Cont

\begin{tabular}{|c|c|c|c|c|c|c|c|c|c|c|}
\hline \multirow[b]{2}{*}{ Species } & \multicolumn{8}{|c|}{ Basins } & \multirow[b]{2}{*}{ F.O. } & \multirow[b]{2}{*}{ Global distribution } \\
\hline & Apodi & Brígida & Jaguaribe & Moxotó & Pajeú & Piranhas & $\begin{array}{c}\text { São } \\
\text { Francisco }\end{array}$ & $\begin{array}{l}\text { Terra } \\
\text { Nova }\end{array}$ & & \\
\hline $\begin{array}{l}\text { Ephemeroporus hybridus (Daday, } \\
\text { 1905) }\end{array}$ & & $\mathrm{X}$ & & & $\mathrm{X}$ & & & & 18.18 & NT; OL \\
\hline $\begin{array}{l}\text { Ephemeroporus tridentatus (Bergamin, } \\
\text { 1939) }\end{array}$ & & $\mathrm{X}$ & & & $\mathrm{X}$ & & & & 4.55 & NT; OL \\
\hline \multicolumn{11}{|l|}{ ALONINAE } \\
\hline Magnospina dentifera (Sars, 1901) & & $\mathrm{X}$ & & & $\mathrm{X}$ & & & & 11.36 & NT \\
\hline Ovalona glabra Sars, 1901 & & $\mathrm{X}$ & & & $\mathrm{X}$ & & $\mathrm{X}$ & & 15.91 & NT \\
\hline Alona guttata Sars, 1862 & & & & & $\mathrm{X}$ & & & & 6.82 & $\begin{array}{l}\text { AT; AU; NA; NT; } \\
\text { OL; PA }\end{array}$ \\
\hline $\begin{array}{l}\text { Flavalona margipluma Sousa, Santos, } \\
\text { Güntzel, Diniz, Melo Junior \& Elmoor- } \\
\text { Loureiro, } 2015\end{array}$ & & & & & $\mathrm{X}$ & & & & 2.27 & - \\
\hline Alona ossiani Sinev, 1998 & & & & & $\mathrm{X}$ & & & & 4.55 & NT \\
\hline Alona sp. & & & & & & & $\mathrm{X}$ & & 4.55 & \\
\hline Anthalona verrucosa (Sars, 1901) & & $\mathrm{X}$ & & $\mathrm{X}$ & $\mathrm{X}$ & & & & 20.45 & NT \\
\hline $\begin{array}{l}\text { Celsinotum laticaudatum Smirnov \& } \\
\text { Santos-Silva, } 1995\end{array}$ & & & & & $\mathrm{X}$ & & & & 2.27 & NT \\
\hline Coronatella monacantha (Sars, 1901) & & & & & $\mathrm{X}$ & & & & 2.27 & NT \\
\hline $\begin{array}{l}\text { Coronatella serratalhadensis Sousa, } \\
\text { Elmoor-Loureiro \& Santos, } 2015\end{array}$ & & & & $\mathrm{X}$ & $\mathrm{X}$ & & $\mathrm{X}$ & & 15.91 & NT \\
\hline Euryalona orientalis (Daday, 1898) & & $\mathrm{X}$ & & & $\mathrm{X}$ & & & & 11.36 & AT; AU; NT; OL \\
\hline $\begin{array}{l}\text { Flavalona iheringula (Kotov \& } \\
\text { Sinev, 2004) }\end{array}$ & & & & & $\mathrm{X}$ & & & & 2.27 & NT \\
\hline Karualona muelleri (Richard, 1897) & & $\mathrm{X}$ & & $\mathrm{X}$ & $\mathrm{X}$ & & $\mathrm{X}$ & & 25.00 & NT \\
\hline Kurzia polyspina Hudec, 2000 & & $\mathrm{X}$ & & & $\mathrm{X}$ & & & & 11.36 & NT \\
\hline Leberis davidi (Richard, 1895) & & & & & $\mathrm{X}$ & & & & 11.36 & NT \\
\hline Leygidia sp. & & & & & & & $\mathrm{X}$ & & 6.82 & NT \\
\hline Leydigiopsis curvirostris Sars, 1901 & & $\mathrm{X}$ & & & $\mathrm{X}$ & & & & 2.27 & NT \\
\hline Leydigiopsis ornata Daday, 1905 & & & & & $\mathrm{X}$ & & & & 4.55 & NT \\
\hline Notoalona sculpta (Sars, 1901) & & $\mathrm{X}$ & & & $\mathrm{X}$ & & & & 4.55 & NT \\
\hline Oxyurella longicaudis (Birge, 1910) & & $\mathrm{X}$ & & $\mathrm{X}$ & & & & & 2.27 & \\
\hline \multicolumn{11}{|l|}{ COPEPODA } \\
\hline Nauplii & $\mathrm{X}$ & $\mathrm{X}$ & $\mathrm{X}$ & $\mathrm{X}$ & $\mathrm{X}$ & $\mathrm{X}$ & $\mathrm{X}$ & $\mathrm{X}$ & 95.45 & \\
\hline CALANOIDA & & & & & $\mathrm{X}$ & & & & 4.55 & \\
\hline \multicolumn{11}{|l|}{ DIAPTOMIDAE } \\
\hline Argyrodiaptomus sp. & $\mathrm{X}$ & & & & & $\mathrm{X}$ & $\mathrm{X}$ & & 9.09 & \\
\hline $\begin{array}{l}\text { Notodiaptomus cearensis (Wright, } \\
\text { 1936) }\end{array}$ & $\mathrm{X}$ & & & $\mathrm{X}$ & $\mathrm{X}$ & $\mathrm{X}$ & $\mathrm{X}$ & & 31.82 & NT \\
\hline Notodiaptomus iheringi (Wright, 1935) & & $\mathrm{X}$ & & & & & & & 4.55 & NT \\
\hline CYCLOPOIDA & & & & $\mathrm{X}$ & $\mathrm{X}$ & & $\mathrm{X}$ & & 34.09 & \\
\hline \multicolumn{11}{|l|}{ CYCLOPIDAE } \\
\hline $\begin{array}{l}\text { Thermocyclops decipiens (Kiefer, } \\
\text { 1929) }\end{array}$ & $\mathrm{X}$ & $\mathrm{X}$ & & & & $\mathrm{X}$ & & & 11.36 & NT \\
\hline Thermocyclops sp. & & $\mathrm{X}$ & & & & & & & 11.36 & \\
\hline Eucyclops neumani (Pesta, 1927) & & $\mathrm{X}$ & & & & & & & 11.36 & NT \\
\hline Ectocyclops herbstii Dussart, 1984 & & $\mathrm{X}$ & & & & & & & 11.36 & NT \\
\hline Paracyclops sp. & & & & & & $\mathrm{X}$ & & & 2.27 & \\
\hline HARPACTICOIDA & & $\mathrm{X}$ & & & & $\mathrm{X}$ & & & 6.82 & \\
\hline Total richness & 5 & 31 & 1 & 13 & 41 & 9 & 16 & 5 & & \\
\hline
\end{tabular}


The genus composition was different among hydrographic basins $(F=1.88 ; p=0.0051)$ (Fig. 3). The Cluster analysis, considering hydrographic basins, indicated three major groups: Group 1- Terra Nova (Pernambuco) and Piranhas (Paraíba and Rio Grande do Norte), group 2Pajeú and Brígida (both in Pernambuco) and group 3- São Francisco (Pernambuco), and Apodi (Rio Grande do Norte). The Moxotó River basin (Pernambuco) was isolated from the rest (Fig. 4).

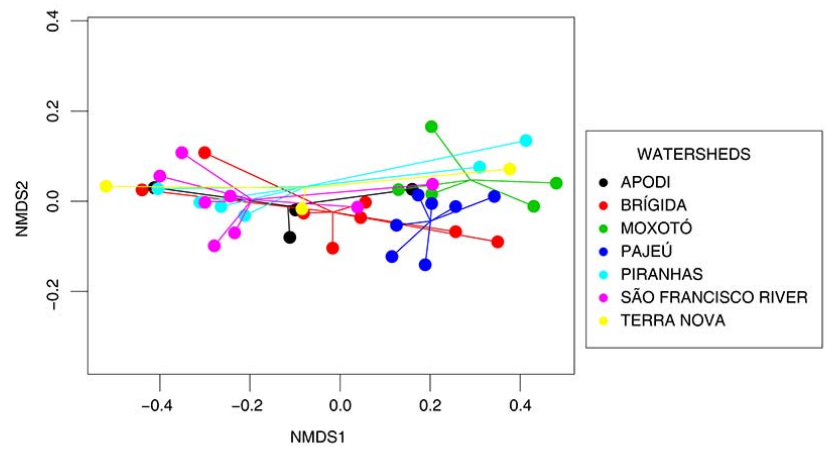

Fig. 3. Non-metric multidimensional scaling considering the composition data of the microcrustaceans from seven basins in the semiarid region of northeastern Brazil.

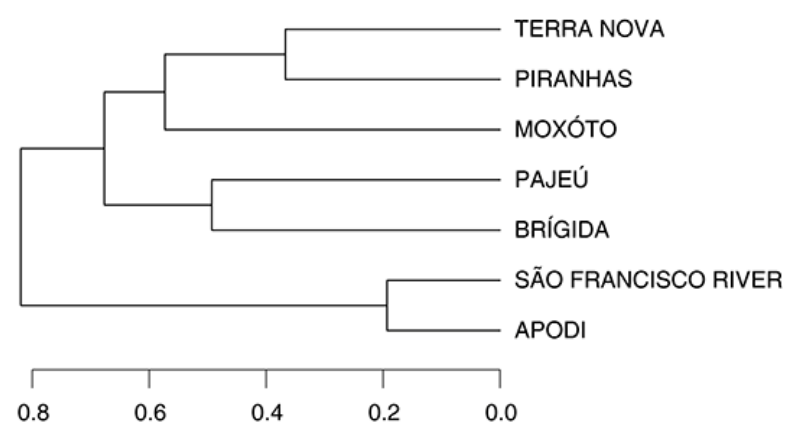

Fig. 4. Cluster analysis of samples from the seven basins of the semiarid region in northeastern Brazil.

The greatest density values for cladocerans were recorded in the Terra Nova River basin $(58,524.2 \pm 101,366.8$ ind. $\left.\mathrm{m}^{3}\right)$, Moxotó $\left(50,495.2 \pm 70,015.9\right.$ ind. $\left.\mathrm{m}^{3}\right)$ and Brígida $\left(43,353.7 \pm 99,886.6\right.$ ind. $\left.\mathrm{m}^{3}\right)$. For copepods, the Moxotó River basin presented the highest density $(426,076.2 \pm 505,754.2$ ind. $\left.\mathrm{m}^{3}\right)$, followed by Piranhas $(190,529.98 \pm 270,111.2$ ind. $\mathrm{m}^{3}$ ) and Jaguaribe (single sample with 155,2162.85 ind. $\mathrm{m}^{3}$ ) (Fig. 5).

\section{CLADOCERA}

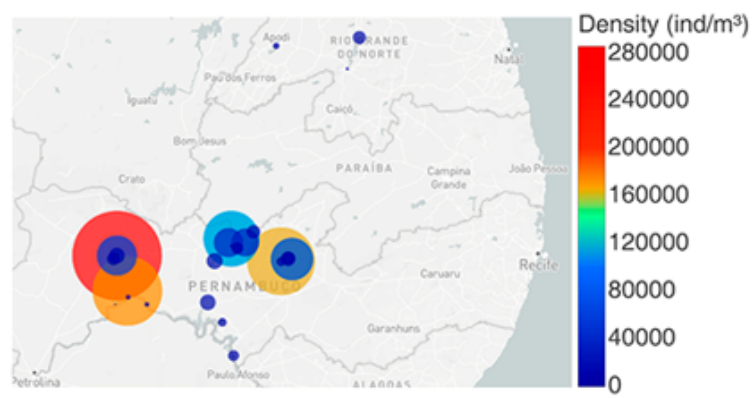

\section{DISCUSSION}

Richness and abundance patterns were higher in basins where sampling was performed mainly in lentic environments, such as Pajeú and Moxotó. However, a clear species distribution pattern was not found among the studied basins. This could reflect the non-systematic collection method used. In addition, there are considerable differences regarding endemism between the basins, with Pajeú presenting the highest number of exclusive species, probably because the highest number of environments was sampled from this basin.

The knowledge of limnic microcrustaceans from 18 years ago was considered insufficient in Brazil (ELMOoRLOUREIRO, 2000), and currently, even with new research, little progress has been made to fill this gap, especially when considering the Northeastern region (Silva \& PerbicheNeves, 2017). According to Silva (2008), the endemism record per region is related to the number of specialists in each area, which makes it difficult, or even impossible, to compare results between regions. Primary studies like biological inventories are considered one of the most important tools for management and conservation measures in a given area (SiLVeIRa et al., 2010).

Considering recent surveys of cladoceran fauna in Pernambuco (SoARes \& ElMOOR-LouReIro, 2011; DinIZ et al., 2013; Sousa et al., 2015a,b), 55 species were verified in the state. With this study, we add seven new species to Pernambuco's list of cladoceran species. Thus, these new occurrences (Celsinotum laticaudatum Smirnov \& SantosSilva, 1995, Diaphanosoma fluviatile Hansen, 1899, D. polyspinum Korovchinsky, 1982, Flavalona iheringula (Kotov \& Sinev, 2004), Moina reticulata (Daday, 1905), Pseudosida bidentata Herrick, 1884 and Simocephalus serrulatus (Koch, 1841) increase the total number of known species to 62 for the state. Such increase in species for Pernambuco shows the importance of biodiversity inventories and reiterates that further research is still needed to determine the true biodiversity of aquatic invertebrates, especially for the semiarid region.

The cladocerans Ceriodaphnia cornuta, Diaphanosoma spinulosum and Moina micrura occurred in most of the studied environments. In the Brazilian Northeastern region, aquatic environments are generally

Fig. 5. Density of microcrustaceans (cladocerans and copepods) distributed in the eight basins of the semiarid region in northeastern Brazil. 
dominated by these species, mainly in reservoirs from Pernambuco (Medeiros \& Melo-Júnior, 2016), Rio Grande do Norte (EskinaZI-SANT'AnNa et al., 2007), Bahia (SANTOS et al., 2018), and Piauí (PARANHos et al., 2013). The presence of Karualona muelleri (Richard, 1897) in half of the studied ecosystems (all in Pernambuco) reinforces the importance of studying aquatic environments such as ponds, river stretches and temporary pools, since this species has never been reported after 34 years of studying Pernambuco reservoirs (MEDEIROs \& MELO-JÚNIOR, 2016).

Calanoida and Cyclopoida are the most common orders in these environments, with dominance of the families Diaptomidae and Cyclopidae in South America; the former endemic to the Neotropical region (Boxshall \& DafaYe, 2008). In the Brazilian northeastern region, the species Notodiaptomus cearensis (Diaptomidae) and Thermocyclops decipiens (Kiefer, 1929) (Cyclopidae) were reported from several reservoirs in Pernambuco (MedeIRos \& MELO JÚNIOR, 2016), Bahia (Santos et al., 2018), Piauí (Paranhos et al., 2013) and Rio Grande do Norte (EskinAZI-SANT'ANNA et al., 2007). In general, these species are associated with the trophic state of the environment, with Cyclopoida being dominant in eutrophic environments (PINTO-Coelho et al., 2005). However, for the state of Rio Grande do Norte, the predominance of Calanoida in impacted environments has also been reported (PANOsso et al., 2007; EsKINAZISANT'AnNa et al., 2007). Notodiaptomus, for example, may consume small cyanobacterial colonies, favoring them in eutrophic environments (PANOSSO et al., 2007). In our study, Notodiaptomus cearensis was the most common species. Although we did not measure the trophic state of the waterbodies, most of them suffer from eutrophication (Bouvy et al., 2001; EskinAZI-SANT'ANNA et al., 2013; Diniz \& Melo-JÚNIOR, 2017), which could explain the dominance of this calanoid copepod.

We did not find a clear distribution pattern for the species. However, concerning endemism, there were considerable differences between the basins, in which the Pajeú presented the highest number of exclusive species (17). Several factors may be responsible for endemism, such as the presence of aquatic macrophytes (PERBICHE-NEvES et al., 2014). Since we did not measure the physicochemical variables of water, nor have detailed information about the littoral zone of the areas, it is difficult to establish patterns. However, the highest number of studied environments come from this basin, which may explain the highest number of exclusive species recorded (Silva, 2008). While some species were recorded in certain basins, others were widely distributed (see Tab. II). For example, $N$. cearensis occurred in almost all basins. This is expected since members of Diaptomidae are distributed almost everywhere in the world, being even more diverse in the Neotropical region (DUSSART \& DefaYe, 2002).

Sampling in a non-systematic way, regarding periodicity, as well as the occasional sampling events, could have possibly hindered the real estimation of microcrustacean taxonomic composition, since some rare species might not have been sampled (PARANHOS et al., 2013). This

Tab. II. List of water bodies in the semiarid ecosystems, Brazil where microcrustaceans have already been studied (*indicate articles that did not study certain groups - Cladocera or Copepoda).

\begin{tabular}{|c|c|c|c|c|c|c|}
\hline Reference & State & Basins & $\begin{array}{c}\text { Environment } \\
\text { type }\end{array}$ & $\begin{array}{c}\text { Number of } \\
\text { environments }\end{array}$ & $\begin{array}{l}\text { Cladocera } \\
\text { richness }\end{array}$ & $\begin{array}{c}\text { Copepoda } \\
\text { richness }\end{array}$ \\
\hline CRISPIM \& WatANABE, 2000 & $\mathrm{CE}$ & River Jaguaribe & Reservoir, river & 3 & 4 & 5 \\
\hline Present study & $C E$ & River Jaguaribe & Reservoir & 1 & * & 1 \\
\hline Present study & $R N$ & River Apodi & Reservoir, river & 4 & 1 & 3 \\
\hline ESKINAZI-SANT'ANNA et al., 2007 & $\mathrm{RN}$ & River Piranhas-assu & Reservoir & 6 & 9 & 9 \\
\hline Medeiros et al., 2011 & $\mathrm{RN}, \mathrm{PB}$ & River Piranhas-assu & River, stream and reservoir & 3 & 4 & 2 \\
\hline Crispim \& Watanabe, 2000 & $\mathrm{RN}, \mathrm{PB}$ & River Piranhas-assu & Reservoir, river & 4 & 8 & 3 \\
\hline Present study & $R N, P B$ & River Piranhas-assu & River, stream and reservoir & 6 & 3 & 5 \\
\hline Melo \& Medeiros, 2013 & $\mathrm{~PB}$ & River Paraíba & River & 3 & 6 & 4 \\
\hline Crispim \& Freitas, 2005 & $\mathrm{~PB}$ & River Paraíba & Lagoon & 1 & 9 & $*$ \\
\hline VIEIRA et al., 2009 & PB & River Paraíba & Reservoir & 1 & 9 & $*$ \\
\hline CRISPIM et al., 2006 & PB & River Paraíba & Reservoir & 5 & 12 & $*$ \\
\hline Present study & $P E$ & River Moxotó & Reservoir & 4 & 10 & 2 \\
\hline MedeIros et al., 2011 & $\mathrm{PE}$ & River Moxotó & Stream & 1 & 0 & 2 \\
\hline MEdeiros et al., 2011 & PE & River Ipanema & Reservoir & 1 & 4 & 2 \\
\hline Melo et al., 2014 & $\mathrm{PE}$ & River Ipanema & Reservoir, stream & 4 & 3 & 2 \\
\hline MEDEIRos et al., 2011 & $\mathrm{PE}$ & River Una & Reservoir & 1 & 3 & 3 \\
\hline Present study & $P E$ & River Pajeú & Reservoir & 9 & 37 & 3 \\
\hline Present study & $P E$ & River Brígida & Reservoir & 8 & 24 & 6 \\
\hline Present study & $P E$ & River São Francisco & River, stream and reservoir & 8 & 12 & 3 \\
\hline Present study & $P E$ & River Terra Nova & River & 3 & 4 & 1 \\
\hline
\end{tabular}


may justify the fact that, although the Pajeú River basin presented the highest richness and largest sample effort, the extrapolated number of species still shows an increasing tendency. Moreover, most of the samples were collected from reservoirs and small ponds in this basin. SHARMA et al. (2012), studying lakes in India, concluded that the depth of the spring, commonly shallow waters, combined with other factors, such as homogeneous distribution of light incidence, contribute the most to the higher richness and composition of these invertebrates.

The Moxotó basin, in Pernambuco, presented the highest abundance of cladocerans and copepods. All samplings in this area were only carried out in lentic environments which could favour their development (TAKAHASHI et al., 2009). Their eating habits, reproductive and morphological strategies could also explain the great temporal and even spatial variation of their community structure. Besides being characterized as lentic environments, the studied environments in this basin are also temporary. Thus, another possible reason for greater zooplankton abundance may be the reduction or even absence of fish in temporary environments. For example, DRENNER et al. (2009) found a predominance of larger sized zooplankton organisms in the absence of fish in temporary ponds.

The species composition was different among river basins, which was already expected since sampling events were carried out in environments with distinct features (lotic and lentic stretches - reservoirs and temporary ponds). MERRIX-JONES et al. (2013), who studied natural and artificial ponds from various parts of the world, have observed that the composition of zooplanktonic organisms differs between natural and artificial systems on a global scale. In fact, several factors may be responsible for structuring communities, including environmental heterogeneity, intensity of disturbances, connectivity and dispersion (Vellend, 2010; LOPES et al., 2014). In addition, solar radiation may be a predictor responsible for variation in species composition (Pinel-Alloul et al., 2013).

Comparing the richness values between the studied environments and other works from adjacent basins, we did not find a clear pattern of distribution and diversity in Northeastern basins (see Tab. II). Although average richness of cladocerans was intermediate in the Paraíba river basin, the region still lacks studies about copepod diversity (see Tab. II). Pernambuco basins showed higher average richness of cladocerans, with decreasing tendency towards the northern portion of the Northeastern region ( $\mathrm{RN}$ and $\mathrm{CE}$ ). On the other hand, we found an opposite pattern for copepods, with the highest average richness found in Rio Grande do Norte and Ceará basins.

The multiple uses of aquatic environments in the Brazilian semiarid (EsKINAZI-SANT'ANNA et al., 2007) may lead to eutrophication. Traditional metrics have shown that modifications in a naturally lotic system, transforming it into a lentic one (dam construction, for example), cause changes in species richness, density and composition of the community. Therefore, studies that aim to catalogue the biodiversity of this area are fundamental for conservation of the aquatic biota. In addition, the São Francisco River has a great socioeconomic importance for the states of Pernambuco, Alagoas, Sergipe and Bahia, but its biodiversity is still poorly known and there is a clear need for studies about zooplankton species diversity due to the deterioration of the environmental quality. We also emphasize that future studies and inventories, in the semiarid region should consider the different seasonal periods to maximize understanding of microcrustacean dynamics.

Acknowledgments. We are grateful for the Universidade Federal Rural de Pernambuco/Academic Unit of Serra Talhada (UFRPE/UAST), for logistic support in this work, and the Fundação de Amparo à Ciência e Tecnologia do Estado de Pernambuco - FACEPE (APQ 0664-2.05/10), for financial support. We gratefully acknowledge all the members of the Plankton Ecology Laboratory (LEPLANC) for their help with sampling procedures.

\section{REFERENCES}

Ahlstrom, E. H. 1938. Plankton Rotatoria from Northeast Brazil. Anais da Academia Brasileira de Ciências 10(1):29-51.

Almeida, V. L. S.; Dantas, E. W.; Melo Júnior, M. De.; BittencourtOliveira, M. C. \& Moura, A. N. 2009. Zooplanktonic community of six reservoirs in northeast Brazil. Brazilian Journal of Biology 69(1):57-65.

Anderson, M. J. 2001. A new method for non-parametric multivariate analysis of variance. Austral Ecology 26(2001):32-46.

Bouvy, M.; Pagano, M. \& Trousselier, M. 2001. Effects of a cyanobacterial bloom (Cylindrospermopsis raciborskii) on bacterial and zooplankton communities in Ingazeira reservoir (Northeast, Brazil). Aquatic Microbial Ecology 25(3):215-227.

Boxshall, G. A. \& Defaye, D. 2008. Global diversity of copepods (Crustacea: Copepoda) in freshwater. Hydrobiologia 595:195-207.

BreHM, V. 1937. Brasilianische Cladoceran gesammelt von Dr. O. Schubart. Zweiter Berich. Internationale Revue der gesamten Hydrobiologie und Hydrographie 35:497-512.

BreHM, V. 1938. Dritter Bericht über die von Dr. O. Schubart in Brasilien gesammelten Onychura. Zoologischer Anzeiger 122:94-103.

Brehm, V. \& Thomsen, R. 1936. Brasilianische Phyllopoden Arguliden gesammelt von Hern Dr. O. Schubart. Zoologischer Anzeiger 116:211218.

Cabral, C. R.; Guariento, R. D.; Ferreira, F. C.; Amado, A. M.; Nobre, R. L.; CARneiro, L. S. \& Caliman, A. 2019. Are the patterns of zooplankton community structure different between lakes and reservoirs? A local and regional assessment across tropical ecosystems. Aquatic Ecology 53(3):335-346.

Cardoso, M. M. L.; Souza, J. E. R. T.; Crispim, M. C. \& Siqueira, R. 2012. Diversidade de peixes de um rio intermitente do semiárido paraibano, Brasil. Biotemas 25(3):161-171.

ChaO, A. \& Jost, L. 2012. Coverage-based rarefaction and extrapolation: Standardizing samples by completeness rather than size. Ecology 93:2533-2547.

Crispim, M. C. \& Freitas, G. T. P. 2005. Seasonal effects on zooplanktonic community in a temporary lagoon of northeast Brazil. Acta Limnologica Brasiliensia 17(4):385-393.

Crispim, M. C.; Ribeiro, L. L.; Gomes, E. M.; Freitas, G. T. P. \& Serpe, F. R. 2006. Comparision of different kind of semi-arid aquatic environments based on zooplankton communities. Revista de Biologia e Ciências da Terra 1:98-111.

Crispim, M. C. Watanabe, T. 2000. Caracterização limnológica das bacias doadoras e receptoras de águas do rio São Francisco: 1-Zooplâncton. Acta Limnologica Brasiliensia 12(2):93-103.

Debastiani-Júnior, J. R.; Elmoor-Loureiro, L. M. A. \& Nogueira, M. G. 2015. High taxonomic resolution as a determinant on finding new species and new records in the Río de La Plata basin: a case on Chydoridae (Crustacea: Branchiopoda: Cladocera). Nauplius 23(1):21-30. 
Diniz, L. P.; Elmoor-Loureiro, L. M. A.; Almeida, V. L. S. \& Melo JÚNIOR, M. DE. 2013. Cladocera (Crustacea, Branchiopoda) of a temporary shallow pond in the Caatinga of Pernambuco, Brazil. Nauplius 21(1):65-78.

DinIZ, L. P. \& Melo-JúNIOR, M. 2017. Can nearby eutrophic reservoirs sustain a differentiated biodiversity of planktonic microcrustaceans in a tropical semiarid basin? Anais da Academia Brasileira de Ciências 89(4):2771-2783.

Drenner, S. M.; Dodson, S. I.; Drenner, R. W. \& Pinder III, J. E. 2009. Crustacean zooplankton community structure in temporary and permanent grassland ponds. Hydrobiologia 632(1):225-233.

Dussart, B. H. \& Defaye, D. 2002. World Directory of Crustacea Copepoda of Inland Waters. I - Calaniformes. Leyden, Backhuys Publ. 276p.

Elmoor-Loureiro, L. M. A. 1997. Manual de Identificação de Cladóceros Límnicos do Brasil. Brasília, Universo. 155p.

Elmoor-Loureiro, L. M. A. 2000. Brazilian cladocera studies: where do we stand? Nauplius 8(1):117-131.

Eskinazi-Sant'Anna, E. M.; Menezes, R.; Costa, I. S.; Araújo, M.; Panosso, R. \& Attayde, J. L. 2013. Zooplankton assemblages in eutrophic reservoirs of the Brazilian semi-arid. Brazilian Journal of Biology 73:37-52.

Eskinazi-Sant'anna, E. M.; Menezes, R.; Costa, I. S.; Panosso, R. F.; AraúJo, M. F. \& Attayde, J. L. 2007. Composição da comunidade zooplanctônica em reservatorios eutrófios do semiárido do rio grande do norte. Oecologia Brasiliensis 11(3):410-421.

Forró, L.; Korovchinsky, N. M.; Kotov, A. A. \& Petrusek, A. 2008. Global diversity of cladocerans (Cladocera; Crustacea) in freshwater. Hydrobiology 595:177-184.

GüntZel, A. M.; Panarelli, E. A.; Da Silva, W. M. \& Roche, K. F. 2010. Influence of connectivity on Cladocera diversity in oxbow lakes in the Taquari River floodplain (MS, Brazil). Acta Limnologica Brasiliensia 22(1):93-101.

Hsien, T. C.; MA, K. H. \& ChaO, A. 2016. iNEXT: an R package for rarefaction and extrapolation of species diversity (Hill numbers). Methods in Ecology and Evolution 7:1451-1456.

Lopes, P. M.; Bini, L. M.; Declerck, S. A. J.; Farjalla, V. F.; Vieira, L. C. G.; Bonecker, C. C.; LansaC-Toha, F. A.; Esteves, F. A. \& Bozelli, R. L. 2014. Correlates of Zooplankton Beta Diversity in Tropical Lake Systems. PlosOne 9:1-8.

MaltchiK, L. \& Medeiros, E. S. F. 2006. Conservation importance of semi-arid streams in north-eastern Brazil: implications of hydrological disturbance and species diversity. Aquatic Conservation 16(7):665677.

Matsumura-Tundisi, T. 1986. Latitudinal distribution of Calanoida copepods in freshwater aquatic systems of Brazil. Revista Brasileira de Biologia 43(3):527-553.

Medeiros, E. S. F. \& MaltchiK, L. 2001. Fish assemblage stability in an intermittently flowing stream from the Brazilian semiarid region. Austral Ecology 26(2):156-164.

Medeiros, E. S.; Noia, N. P.; Antunes, L. C. \& Melo, T. X. 2011. Zooplankton composition in aquatic systems of semi-arid Brazil: spatial variation and implications of water management. Pan-American Journal of Aquatic Sciences 6(4):290-302.

Medeiros, I. L. S. \& Melo-Júnior, M. 2016. Composição e Síntese dos Conhecimentos sobre o zooplâncton de Reservatórios de Pernambuco. Revista Nordestina de Zoologia 10(1):44-69.

Melão, M. G. G.; Rocha, O. \& Roche, K. F. 2005. Produtividade, biomassa, flutuações populacionais e interações biológicas da comunidade planctônica e suas implicações na transferência de energia na cadeia alimentar de um reservatório raso e oligotrófico. In: RocHE, K. F. \& Rocha, O. eds. Ecologia Trófica de Peixes com ênfase na planctivoria em ambientes lênticos de água doce no Brasil. São Carlos, Rima, p. 25-80.

Melo, T. X.; Lourenço, L. J. S. \& Medeiros, E. S. F. 2014. Checklist of zooplankton from the upper ipanema river (Pernambuco), an intermittent river in semi-arid Brazil. Check List 10(3):524-528.

Melo, T. X. \& Medeiros, E. S. F. 2013. Spatial distribution of zooplankton diversity across temporary pools in a semiarid intermittent river. International Journal of Biodiversity 2013:1-13.
Melo-júnior, M. de; Almeida, V. L. S. ; Paranaguá, M. N. \& Moura, A. N. 2007. Crustáceos planctônicos de um reservatório oligotrófico do Nordeste do Brasil. Revista Brasileira de Zoociências 9:19-30.

Merrix-Jones, F. L.; Thackeray, S. J. \& Ormerod, S. J. 2013. A global analysis of zooplankton in natural and artificial fresh waters. Journal of Limnology 72(1):140-153.

Meyer, D. \& Buchta, C. 2018. proxy: Distance and Similarity Measures. $R$ package version 0.4-21. Available at $<\mathrm{http}$ //CRAN.R-project.org/ package $=$ proxy $>$.

MMA. 2006a. Caderno da Região Atlântico Nordeste Oriental. Brasília, Ministério do Meio Ambiente, Secretaria de Recursos Hídricos. 104p.

MMA. 2006b. Caderno da Região Hidrográfica do São Francisco. Brasília, Ministério do Meio Ambiente, Secretaria de Recursos Hídricos. $148 \mathrm{p}$.

Moreira, R. A.; Mansano, A. D. S.; Silva, L. C. D. \& Rocha, O. 2014. A comparative study of the acute toxicity of the herbicide atrazine to cladocerans Daphnia magna, Ceriodaphnia silvestrii and Macrothrix flabelligera. Acta Limnologica Brasiliensia 26(1):1-8.

Neumann-Leitão, S.; Nogueira-Paranhos, J. D. \& Souza, F. B. V. A. 1989. Zooplâncton do Açude de Apipucos, Recife - PE (Brasil). Arquivos de Biologia e Tecnologia 32(4):803-821.

Neumann-Leitão, S. \& Souza, F. B. V. A. 1987. Rotíferos (Rotatoria) planctônicos do Açude de Apipucos, Recife - Pernambuco (Brasil). Arquivos de Biologia e Tecnologia 30(3):393-418.

Nordi, N. \& Watanabe, T. 1978. Nota preliminar sobre os rotíferos (zooplâncton) do açude Epitácio Pessoa, Boqueirão, Paraíba. Revista Nordestina de Biologia 1(1):31-39.

OKSANEN, J. et al. 2018. Vegan: community ecology package. R Package Version 2. 4-6. Available at $<$ https://cran.r-project.org/web/packages/ vegan/vegan.pdf $>$.

Panosso, R.; Costa, I. A. S.; Souza, N. R.; Cunha, S. R. S.; Attayde, J. L. \& Gomes, F. C. F. 2007. Cianobactérias e Cianotoxinas em reservatórios do Estado do Rio Grande do Norte e o potencial controle das florações pela tilápia do nilo (Oreochromis niloticus). Oecologia Brasiliensis 11(3):433-449.

Paranhos, J. D. N.; Almeida, V. L. S.; Silva Filho, J. P.; Paranaguá, M. N. \& Melo Júnior, M. DE \& Neumann-Leitão, S. 2013. The zooplankton biodiversity of some freshwater environments in Parnaíba basin (Piauí, Northeastern Brazil). Brazilian Journal of Biology 73:125-134.

Perbiche-Neves, G.; Boxshall, G. A.; Previattelli, D.; Nogueira, M. G. \& Rocha, C. E. F. 2015. Identification guide to some Diaptomid species (Crustacea, Copepoda, Calanoida, Diaptomidae) of "de la Plata" River Basin (South America). ZooKeys 497:1-111.

Perbiche-Neves, G.; Rocha, C. E. F. \& Nogueira, M. G. 2014. Estimating cyclopoid copepod species richness and geographical distribution (Crustacea) across a large hydrographical basin: comparing between samples from water column (plankton) and macrophyte stands. Zoologia 31(3):239-244.

Pinel-Alloul, B.; André, A.; Legendre, P.; Cardille, J. A.; Patalas, K. \& SALKI, A. 2013. Large-scale geographic patterns of diversity and community structure of pelagic crustacean zooplankton in Canadian lakes. Global Ecology and Biogeography 22(7):784-795.

Pinto-Coelho, R. M.; Pinel-Alloul, B.; Méthot, G. \& Havens, K. E. 2005. Crustacean zooplankton in lakes and reservoirs of temperate and tropical regions: variation with trophic status. Canadian Journal of Fisheries and Aquatic Science 62:348-361.

R Core Team. 2016. R: A language and environment for statistical computing. R Foundation for Statistical Computing. Vienna, Austria. Available at $<$ http://www.r-project.org. $>$

REID, J. W. 1985. Chave de identificação e lista de referências bibliográficas para espécies continentais sul-americanas de vida livre da ordem Cyclopoida (Crustacea, Copepoda). Boletim de Zoologia 9:17-143.

ReID, J. W. 1989. The distribution of species of the genus Thermocyclops (Copepoda, Cyclopoida) in the western hemisphere, with description of T. parvus, new species. Hydrobiologia 175(2):149-174.

Reid, J. W. \& Turner, P. N. 1988. Planktonic Rotifera, Copepoda and Cladocera from Açú and Viana lakes, State of Maranhão, Brazil. Brazilian Journal of Biology 48(3):485-495.

Santos, J. S.; Simões, N. R. \& Sonoda, S. L. 2018. Spatial distribution and temporal variation of microcustaceans assembly (Cladocera and 
Copepoda) in different compartments of a reservoir in the Brazilian semiarid region. Acta Limnologica Brasiliensia 30:e108.

Schubart, O. 1938. Considerações sobre as investigações nas águas de Pernambuco. Arquivos Instituto de Pesquisas Agronômicas de Pernambuco 1(1):26-57.

SCHUBART, O. 1942. Fauna do estado de Pernambuco e estados limítrofes: segunda lista. Boletim do Museu Nacional 14(17):21-64.

Sharma, V.; Verma, B. K.; Sharma, R.; Sharma, M. S. \& Gaur, K. S. 2012. A reportonthe freshwater Cladocera (Crustacea: Branchiopoda) of South Rajasthan (India). International Journal of Environmental Sciences 3(1):276-296.

Shatova, O.; Koweek, D.; Conte, M. H. \& Weber, J. C. 2012. Contribution of zooplankton fecal pellets to deep ocean particle flux in the Sargasso Sea assessed using quantitative image analysis. Journal of Plankton Research 34(10):905-921.

SiLVA, W. M. 2008. Diversity and distribution of the free-living freshwater Cyclopoida (Copepoda: Crustacea) in the Neotropics. Brazilian Journal of Biology 68:1099-1106.

Silva, W. M. 2011. Potencial de uso de Cyclopoida (Crustacea, Copepoda) como indicadores do estado trófico em reservatórios tropicais. Oecologia 15(3):511-521.

Silva, W. M. \& Perbiche-Neves, G. 2017. Trends in freshwater microcrustaceans studies in Brazil between 1990 and 2014. Brazilian Journal of Biology 77(3):527-534.

Silveira, L. F.; Beisiegel, B. M.; Curcio, F. F.; Valdujo, P. H.; Dixo, M.; Verdade, V. K.; Mattox, G. M. T. \& Cunningham, P. T. M. 2010. Para que servem os inventários de fauna? Estudos avançados 24(68):173-207.
Smirnov, N. N. 1996. Cladocera: the Chydoridae and Sayciinae (Chydoridae) of the word. Guides to the identification of microinvertebrates of the continental waters of the world, number 11. Amsterdam, Academic Publishing. 197p.

SOARES, C. E. A. \& Elmoor-Loureiro, L. M. A. 2011. Uma atualização da lista de Cladocera Cladocera (Crustacea, Branchiopoda) do Estado de Pernambuco, Brasil. Biota Neotropica 11(2):1-6.

Sousa, F. D. R.; Elmoor-Loureiro, L. M. A. \& Santos, S. 2015a. Redescription of Coronatella poppei (Richard, 1897) (Crustacea, Branchiopoda, Chydoridae) and a revision of the genus in Brazil, with description of new taxa. Zootaxa 3955:211-244.

SOUSA, F. D. R.; SANDRO, S.; GÜNTZEL, A. M.; DinIZ, L. P.; MELO-JÚNIOR, M. \& Elmoor-Loureiro, L. M. A. 2015b. Description of a new species of the costata-group (Cladocera, Chydoridae, Aloninae) from Brazil. Zootaxa 4040:445-457.

Takahashi, E. M.; Lansac-Tôha, F. A.; Dias, J. D.; Bonecker, C. C. \& VelHo, L. F. M. 2009. Spatial variations in the zooplankton community from the Corumbá Reservoir, Goiás State, in distinct hydrological periods. Acta Scientiarum, Biological Sciences 31(3):227-234.

Vellend, M. 2010. Conceptual synthesis in community ecology. The Quarterly Review of Biology 85(2): 183-206.

Vieira, A. C. B.; Ribeiro, L. L.; SANtos, D. P. N. \& CrisPim, M. C. 2009. Correlationbetween the zooplanktonic community and environmental variables in a reservoir from the northeastern semi-arid. Acta Limnologica Brasiliensia 21(3):349-358.

Wright, S. 1935. Three new species of Diaptomus from northeast Brazil. Anais da Academia Brasileira de Ciências 7:213-233. 
Appendix. Codes and coordinates of the studied springs, city/state, type of environment, filtered volume (in liters), amount of sample collected in each spring (quant.) and sampling period (month/year) in semiarid ecosystems, Brazil (RN, Rio Grande do Norte; PE, Pernambuco; CE, Ceará; PB, Paraíba).

\begin{tabular}{|c|c|c|c|c|c|c|}
\hline Springs/ codes & Coordinates & City/state & $\begin{array}{c}\text { Type of } \\
\text { environment }\end{array}$ & $\mathrm{L}$ & Quant. & Month/year \\
\hline \multicolumn{7}{|l|}{$\begin{array}{l}\text { Basins } \\
\text { Apodi }\end{array}$} \\
\hline A1 & $06^{\circ} 21^{\prime} 12^{\prime \prime} \mathrm{S}, 38^{\circ} 11^{\prime} 41^{\prime \prime} \mathrm{W}$ & Pau dos Ferros/RN & River & 393 & 1 & $04 / 2016$ \\
\hline A2 & $06^{\circ} 08^{\prime} 50^{\prime \prime} \mathrm{S}, 38^{\circ} 11^{\prime} 37^{\prime \prime} \mathrm{W}$ & Pau dos Ferros/RN & Reservoir & 393 & 1 & $04 / 2016$ \\
\hline A3 & $05^{\circ} 45^{\prime} 37^{\prime \prime} \mathrm{S}, 37^{\circ} 48^{\prime} 08^{\prime \prime} \mathrm{W}$ & Apodi/RN & Reservoir & 393 & 1 & $04 / 2016$ \\
\hline A4 & $05^{\circ} 34^{\prime} 36^{\prime \prime} \mathrm{S}, 37^{\circ} 41^{\prime} 47^{\prime \prime} \mathrm{W}$ & Apodi/RN & River & 393 & 1 & $04 / 16$ \\
\hline \multicolumn{7}{|l|}{ Brígida } \\
\hline B1 & $07^{\circ} 59^{\prime} 34^{\prime \prime} \mathrm{S}, 39^{\circ} 33^{\prime} 55^{\prime \prime} \mathrm{W}$ & Parnamirim/PE & Reservoir & 393 & 1 & $04 / 16$ \\
\hline $\mathrm{B} 2$ & $08^{\circ} 13^{\prime} 43^{\prime \prime} \mathrm{S}, 39^{\circ} 53^{\prime} 42^{\prime \prime} \mathrm{W}$ & Parnamirim/PE & Reservoir & 393 & 1 & $04 / 16$ \\
\hline B3 & $08^{\circ} 04.097^{\prime} \mathrm{S}, 39^{\circ} 34.403^{\prime} \mathrm{W}$ & Parnamirim/PE & Reservoir & 100 & 2 & $05 / 13$ \\
\hline B4 & $08^{\circ} 05.183^{\prime} \mathrm{S}, 39^{\circ} 34.694^{\prime} \mathrm{W}$ & Parnamirim/PE & Reservoir & $4-30$ & 4 & $05 / 11$ \\
\hline B5 & $08^{\circ} 07.296^{\prime} \mathrm{S}, 39^{\circ} 37.074^{\prime} \mathrm{W}$ & Parnamirim/PE & Reservoir & 100 & 2 & $05 / 13$ \\
\hline B6 & $08^{\circ} 05.169^{\prime} \mathrm{S}, 39^{\circ} 34.648^{\prime} \mathrm{W}$ & Parnamirim/PE & Reservoir & 10 & 1 & $04 / 13$ \\
\hline B7 & $08^{\circ} 34^{\prime} 53^{\prime \prime} \mathrm{S}, 39^{\circ} 33^{\prime} 12^{\prime \prime} \mathrm{W}$ & Orocó/PE & River & 393 & 1 & $05 / 16$ \\
\hline B8 & $08^{\circ} 05.126^{\prime} \mathrm{S}, 39^{\circ} 34.819^{\prime} \mathrm{W}$ & Parnamirim/PE & Reservoir & $70-150$ & 2 & $04 / 13$ \\
\hline \multicolumn{7}{|l|}{ Jaguaribe } \\
\hline $\mathrm{J} 1$ & $07^{\circ} 38^{\prime} 26^{\prime \prime} \mathrm{S}, 38^{\circ} 53^{\prime} 34^{\prime \prime} \mathrm{W}$ & Brejo Santo/CE & Reservoir & 393 & 1 & $04 / 16$ \\
\hline \multicolumn{7}{|l|}{ Moxotó } \\
\hline M1 & $08^{\circ} 07^{\prime} 13.3^{\prime \prime} \mathrm{S}, 37^{\circ} 40^{\prime} 12.6^{\prime \prime} \mathrm{W}$ & Custódia/PE & Lagoon & 2 & 1 & $02 / 11$ \\
\hline M2 & $08^{\circ} 06^{\prime} 59.3^{\prime \prime} \mathrm{S}, 37^{\circ} 39^{\prime} 55.2^{\prime \prime} \mathrm{W}$ & Custódia/PE & Lagoon & 14 & 1 & $07 / 11$ \\
\hline M3 & $08^{\circ} 08^{\prime} 56.5^{\prime \prime} \mathrm{S}, 37^{\circ} 44^{\prime} 53.8^{\prime \prime} \mathrm{W}$ & Custódia/PE & Lagoon & 2 & 1 & $01 / 11$ \\
\hline M4 & $08^{\circ} 09^{\prime} 08.3^{\prime} \mathrm{S}, 37^{\circ} 44^{\prime} 55.0^{\prime \prime} \mathrm{W}$ & Custódia/PE & Lagoon & 2 & 1 & $01 / 11$ \\
\hline M5 & $08^{\circ} 07^{\prime} 27.3 ” \mathrm{~S}, 37^{\circ} 37^{\prime} 34.2^{\prime \prime} \mathrm{W}$ & Custódia/PE & Lagoon & 2 & 1 & $02 / 12$ \\
\hline \multicolumn{7}{|l|}{ Pajeú } \\
\hline $\mathrm{P} 1$ & $07^{\circ} 58^{\prime} 41^{\prime \prime} \mathrm{S}, 38^{\circ} 17^{\prime} 59^{\prime \prime} \mathrm{W}$ & Serra Talhada/PE & Reservoir & $30-50$ & 3 & 02 a $05 / 11$ \\
\hline $\mathrm{P} 2$ & $07^{\circ} 56^{\prime} 35^{\prime} \mathrm{S}, 38^{\circ} 20^{\prime} 07^{\prime \prime} \mathrm{W}$ & Serra Talhada/PE & Reservoir & $75-100$ & 6 & $04 / 11$ a $05 / 14$ \\
\hline P3 & $07^{\circ} 56^{\prime} 30.8^{\prime \prime} \mathrm{S}, 38^{\circ} 08^{\prime} 55.0^{\prime \prime} \mathrm{W}$ & Calumbi/PE & River & $42-110$ & 6 & $12 / 11$ a $06 / 12$ \\
\hline P4 & $08^{\circ} 36^{\prime} 09.0^{\prime \prime} \mathrm{S}, 38^{\circ} 33^{\prime} 56.7^{\prime \prime} \mathrm{W}$ & Floresta/PE & River & $30-40$ & 3 & 05 a $06 / 12$ \\
\hline P5 & $08^{\circ} 00^{\prime} 18.6^{\prime \prime} \mathrm{S}, 38^{\circ} 14^{\prime} 10.0^{\prime \prime} \mathrm{W}$ & Serra Talhada/PE & Reservoir & $40-100$ & 16 & $09 / 11$ a $11 / 12$ \\
\hline P6 & $07^{\circ} 59^{\prime} 31^{\prime \prime} \mathrm{S}, 38^{\circ} 17^{\prime} 05^{\prime \prime} \mathrm{W}$ & Serra Talhada/PE & Reservoir & $75-100$ & 14 & $10 / 11$ a $01 / 12$ \\
\hline P7 & $08^{\circ} 08^{\prime} 43^{\prime} \mathrm{S}, 38^{\circ} 29^{\prime} 23^{\prime \prime} \mathrm{W}$ & Serrinha/PE & Reservoir & $66-110$ & 20 & $09 / 11$ a $11 / 12$ \\
\hline P8 & $07^{\circ} 49^{\prime} 22.59^{\prime \prime} \mathrm{S}, 38^{\circ} 3^{\prime} 22.31^{\prime \prime} \mathrm{W}$ & Triunfo/PE & Lagoon & 2,5 & 2 & $07 / 11$ \\
\hline P9 & $07^{\circ} 53^{\prime} 58.2^{\prime \prime} \mathrm{S}, 38^{\circ} 18^{\prime} 09.6^{\prime \prime} \mathrm{W}$ & Serra Talhada/PE & Lagoon & $14-60$ & 3 & $05 / 12$ a $01 / 14$ \\
\hline \multicolumn{7}{|l|}{ Piranhas } \\
\hline $\mathrm{R} 1$ & $06^{\circ} 47^{\prime} 41^{\prime \prime} \mathrm{S}, 37^{\circ} 56^{\prime} 26^{\prime \prime} \mathrm{W}$ & Souza/PB & River & 393 & 1 & $04 / 16$ \\
\hline $\mathrm{R} 2$ & $07^{\circ} 06^{\prime} 33^{\prime \prime} \mathrm{S}, 38^{\circ} 00^{\prime} 32^{\prime \prime} \mathrm{W}$ & Coremas/PB & Reservoir & 393 & 1 & $04 / 16$ \\
\hline $\mathrm{R} 3$ & $06^{\circ} 43^{\prime} 49^{\prime \prime} \mathrm{S}, 37^{\circ} 48^{\prime} 12^{\prime \prime} \mathrm{W}$ & Pombal/PB & River & 393 & 1 & $04 / 16$ \\
\hline R4 & $06^{\circ} 11^{\prime} 57^{\prime \prime} \mathrm{S}, 37^{\circ} 07^{\prime} 47^{\prime \prime} \mathrm{W}$ & Coremas/RN & River & 393 & 1 & $04 / 16$ \\
\hline $\mathrm{R} 5$ & $06^{\circ} 00^{\prime} 58^{\prime \prime} \mathrm{S}, 37^{\circ} 00^{\prime} 31^{\prime \prime} \mathrm{W}$ & $\mathrm{Açu} / \mathrm{RN}$ & Reservoir & 393 & 1 & $04 / 16$ \\
\hline R6 & $05^{\circ} 40^{\prime} 03^{\prime \prime} \mathrm{S}, 36^{\circ} 52^{\prime} 29^{\prime \prime} \mathrm{W}$ & $\mathrm{Açu/RN}$ & Reservoir & 393 & 3 & $04 / 16$ \\
\hline \multicolumn{7}{|l|}{ São Francisco } \\
\hline S1 & $09^{\circ} 11^{\prime} 17.4^{\prime \prime} \mathrm{S}, 38^{\circ} 15^{\prime} 08.6^{\prime \prime} \mathrm{W}$ & Jatobá/PE & River & 50 & 1 & $08 / 12$ \\
\hline S2 & $09^{\circ} 11^{\prime} 46.1^{\prime \prime} \mathrm{S}, 38^{\circ} 16^{\prime} 26.0^{\prime \prime} \mathrm{W}$ & Jatobá/PE & River & 100 & 1 & $08 / 12$ \\
\hline S3 & $09^{\circ} 11^{\prime} 31.1^{\prime \prime} \mathrm{S}, 38^{\circ} 16^{\prime} 38.3^{\prime \prime} \mathrm{W}$ & Jatobá/PE & River & 100 & 1 & $08 / 12$ \\
\hline S4 & $09^{\circ} 11^{\prime} 23.7^{\prime \prime} \mathrm{S}, 38^{\circ} 16^{\prime} 42.2^{\prime \prime} \mathrm{W}$ & Jatobá/PE & River & 200 & 1 & $11 / 12$ \\
\hline S5 & $08^{\circ} 32^{\prime} 40^{\prime \prime} \mathrm{S}, 39^{\circ} 27^{\prime} 16^{\prime \prime} \mathrm{W}$ & Cabrobó/PE & River & 393 & 1 & $05 / 16$ \\
\hline
\end{tabular}


Appendix. Cont.

\begin{tabular}{|c|c|c|c|c|c|c|}
\hline Springs/ codes & Coordinates & City/state & $\begin{array}{c}\text { Type of } \\
\text { environment }\end{array}$ & $\mathrm{L}$ & Quant. & Month/year \\
\hline S6 & $08^{\circ} 49^{\prime} 25^{\prime \prime} \mathrm{S}, 38^{\circ} 24^{\prime} 11^{\prime \prime} \mathrm{W}$ & Petrolândia/PE & Reservoir & 393 & 1 & $05 / 16$ \\
\hline S7 & $08^{\circ} 37^{\prime} 23^{\prime \prime} \mathrm{S}, 39^{\circ} 35^{\prime \prime} \mathrm{W}$ & Orocó/PE & River & 393 & 1 & $05 / 16$ \\
\hline S8 & $08^{\circ} 37^{\prime} 28^{\prime \prime} \mathrm{S}, 39^{\circ} 14^{\prime} 43^{\prime \prime} \mathrm{W}$ & Ibó & River & 393 & 1 & $05 / 16$ \\
\hline \multicolumn{7}{|l|}{ Terra Nova } \\
\hline $\mathrm{T} 1$ & $08^{\circ} 28^{\prime} 35.4^{\prime \prime} \mathrm{S} 39^{\circ} 27^{\prime} 45.4^{\prime \prime} \mathrm{W}$ & Terra Nova/PE & Reservoir & 393 & 1 & $04 / 16$ \\
\hline $\mathrm{T} 2$ & $08^{\circ} 13^{\prime} 45^{\prime \prime} \mathrm{S}, 39^{\circ} 22^{\prime} 25^{\prime \prime} \mathrm{W}$ & Terra Nova/PE & Reservoir & 393 & 1 & $04 / 16$ \\
\hline $\mathrm{T} 3$ & $08^{\circ} 13^{\prime} 36^{\prime \prime} \mathrm{S}, 39^{\circ} 22^{\prime} 23^{\prime \prime} \mathrm{W}$ & Terra Nova/PE & Reservoir & 393 & 1 & $04 / 16$ \\
\hline
\end{tabular}

